\title{
Fish larvae from the Canary region in autumn*
}

\author{
J. M. RODRÍGUEZ \\ Instituto Español de Oceanografía, Centro Oceanográfico de Canarias, Ctra. de San Andrés s/n. \\ 38120 Santa Cruz de Tenerife, Spain. E-mail: josema@ieo.rcanaria.es
}

\begin{abstract}
SUMMARY: In this paper, the taxonomic composition of the fish larvae community in the Canary region in autumn 1991 is presented. In total, 8699 larvae belonging to 58 fish families were studied. 176 taxonomic groups were identified, 149 at species level and the rest were identified at a higher level. The most numerous family and the one that presented the greatest number of species was Myctophidae. The most frequently caught species was Cyclothone braueri. The taxonomic composition (at family level) of the fish larvae community, dominated by four mesopelagic families, was typical of oceanic regions of warm waters. The most remarkable feature of the fish larvae community was its high specific diversity.
\end{abstract}

Key words: ichthyoplankton, fish larvae, taxonomic composition, Canary region.

\section{INTRODUCTION}

The study of the early stages of development of the fish community of the Canary region (Fig. 1) has received very little attention until recently. Therefore, information on the ichthyoplankton of the area is scarce. Rodríguez and Lozano-Soldevilla (1993) and Rodríguez et al. (1996) studied the ichthyoplankton community in a coastal area located south of the island of Tenerife. Badcock and Merrett (1976) described the taxonomic composition of the fish larvae and adults sampled in an oceanic station north of Fuerteventura. Other studies on the ichthyoplankton community of the area are those of Hempel and Weikert (1972), John $(1976,1979)$ and Andres and John (1984), but these are limited to brief and sparse sampling over an extended work area. They list the fish larvae collected in an exclusively oceanic region which, although it overlaps

\footnotetext{
*Received June 26, 1999. Accepted December 23, 1999.
}

our area, does not include the island neritic regions. Therefore, they make only a small contribution to the knowledge of the early stages of development of the neritic fish populations of the Canary Islands.

In this paper the taxonomic composition of fish larvae caught during the cruise Canarias 9110 is described. It can be considered representative of the general composition of the ichthyoplankton community of the Canary region, for the sampling period, since it included both the neritic region (second part of the cruise) and typically oceanic waters (first part of the cruise).

From the taxonomic point of view, the study of the fish larvae that inhabit the Canary region presented various problems. The most important was the lack of previous studies of this type for the area. Also significant was the absence of descriptions of the early stages of development of many of the species that inhabit these waters. The most frequent fish larvae in our hauls belonged to species of oceanic-mesopelagic habitat, since most of the sam- 
pling stations were in oceanic waters. Because these species lack economic interest, they have been less studied than to those species that inhabit neritic waters and have economic-fishing interest.

\section{MATERIAL AND METHODS}

The material studied in this work was obtained during the cruise Canarias 9110 from 17 October to 5 November 1991. This cruise was divided into two parts. In the first, two transects were sampled and two fixed 24-hours stations were occupied. One transect and station were located to the north of the Canary Islands and the other transect and station to the south (Fig. 1). Seven ichthyoplankton hauls were carried out in the north 24-hours station and six hauls in the south 24-hours station. On the second part, 22 stations were sampled, these being arranged in a regular sampling grid around Gran Canaria (Fig. 1). In total, 44 hauls were carried out for ichthyoplankton.

The ichthyoplankton was collected with a Bongo gear of $40 \mathrm{~cm}$ in diameter fitted with nets of $250 \mu \mathrm{m}$ of mesh size. The hauls were oblique, attempting to sample the surface layer down to $200 \mathrm{~m}$ depth, or to $5 \mathrm{~m}$ above the bottom, when the depth was less. The samples obtained were preserved in a solution of $5 \%$ buffered formalin and sea water.

From both samples obtained by the bongo net at each haul, fish larvae were sorted, identified and classified to the lowest possible taxonomic level (specific level, whenever possible). The number of larvae per taxon was transformed into percentages of the total.

The taxonomic organisation of fish larvae followed here is that of Whitehead et al. (1984).

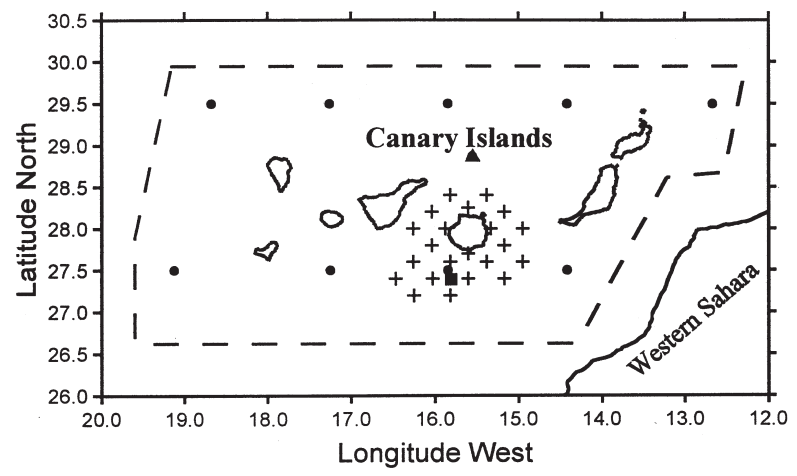

FIG. 1. - Cruise Canarias 9110. Map of stations sampled for ichthyoplankton: $(\bullet)$ north and south transects, $(\boldsymbol{\Delta})$ north 24 hours station and (ם) south 24 hours station, (+) grid of stations sampled during the second part of the cruise. The enclosed area represents the Canary region.

\section{RESULTS}

In total, 8699 larvae belonging to 58 families of fish were studied (Table 1) and 176 taxonomic groups were identified, 149 to species level and the rest to a higher level, genus and families (Table 2). The identifications carried out at specific level included three categories: a) those whose genus and species were recognised (105), b) those where the genus were identified and named, and different species were distinguished with the notation sp., or with this notation followed by a number (25), and c) those which were denominated "larval types" (19). The term "larval type" used here refers to a class of larvae in particular, which can be distinguished from other larvae on the basis of their features but which for various reasons, could not be classified to species level. In some cases, they are doubts that all the larvae included in each one of these "larval types" belong to the same species. That is to say, this term does not necessarily denote identification at specific level and it should be understood that it does not have any taxonomic implication. A total of 197 larvae (2.3\% of the total of fish larvae collected) could not be identified or "typed".

It is necessary to indicate that in Table 2 early stages larvae of Cyclothone pallida and $C$. pseudopallida were grouped due to difficulties in differentiating them. For the same reason, we also grouped the early stage larvae of the three species of Vinciguerria under Vinciguerria spp. These two groups were not considered in the taxonomic recount.

Of the 58 families of fish larvae caught, only six of them exceeded $1 \%$ of total captures (Table 1). Of these six most frequent families, four are mesopelagic oceanics (Myctophidae, Gonostomatidae, Sternoptychidae and Photychthidae) and two are neritics (Gobiidae and Sparidae). These six families contributed $88.8 \%$ of the total fish larvae catches. The myctophids were the dominant group, they represented $60.3 \%$ of the total fish larvae catches and $28.9 \%$ of the identified species. The most captured species was Cyclothone braueri (11.9\% of larvae catches).

Another significant characteristic of the fish larvae community was the relatively important presence $\left(5^{\text {th }}\right.$ place in the rank of frequencies, $2.3 \%$ of the total of fish larvae catches), of the neritic family Gobiidae of which most of its species are very coastal (Hureau and Monod, 1979). Most of the larvae belonging to this family $(98.1 \%)$ were collected from the grid of stations sampled around Gran 
TABLE. 1. - List of the fish larvae families ranked by their percentage of contribution to the total number.

\begin{tabular}{llll}
\hline Family & $\%$ & Family & $\%$ \\
\hline Family Myctophidae & 60.29 & Family Melanocetidae & 0.10 \\
Family Gonostomatidae & 18.36 & Family Serrivomeridae & 0.09 \\
Family Sternoptychidae & 3.38 & Family Tetraodontidae & 0.09 \\
Family Photichthydae & 3.09 & Family Astronesthidae & 0.09 \\
Family Gobiidae & 2.32 & Family Congridae & 0.09 \\
Family Sparidae & 1.38 & Family Evermannellidae & 0.07 \\
Family Gempylidae & 0.91 & Family Macrouridae & 0.07 \\
Family Macroramphosidae & 0.85 & Family Trachinidae & 0.07 \\
Family Paralepididae & 0.66 & Family Carangidae & 0.07 \\
Family Bothidae & 0.55 & Family Serranidae & 0.07 \\
Family Clupeidae & 0.46 & Family Centrolophidae & 0.05 \\
Family Melanostomiidae & 0.47 & Family Ophichthidae & 0.04 \\
Family Labridae & 0.32 & Family Cynoglossidae & 0.04 \\
Family Scopelarchidae & 0.31 & Family Oneirodidae & 0.04 \\
Family Scaridae & 0.29 & Family Scomberosocidae & 0.03 \\
Family Mugilidae & 0.29 & Family Scombridae & 0.03 \\
Family Tetragonuridae & 0.28 & Family Monacanthidae & 0.02 \\
Family Synodontidae & 0.27 & Family Alepisauridae & 0.02 \\
Family Notosudidae & 0.23 & Family Omusudidae & 0.02 \\
Family Nettastomatidae & Family Belonidae & 0.02 \\
Family Chlorophtalmidae & Family Engraulidae & 0.02 \\
Family Chauliodontidae & Family Idiacanthidae & 0.02 \\
Family Trichiuridae & 0.22 & Family Carapidae & 0.02 \\
Family Ophidiidae & 0.20 & Family Soleidae & 0.02 \\
Family Scorpaenidae & 0.20 & Family Gigantactinidae & 0.02 \\
Family Stomiidae & 0.18 & Family Aulopidae & 0.02 \\
Family Bathylagidae & 0.16 & Family Callionymidae & 0.01 \\
Family Nomeidae & 0.15 & Family Caproidae & 0.01 \\
Family Melamphaidae & 0.14 & & \\
\hline & 0.13 & & \\
\end{tabular}

Canaria. Thus, the fish larvae community, although dominated by mesopelagic oceanic species, also presented a relatively important component of larvae of coastal species.

\section{DISCUSSION}

The most remarkable characteristic of the fish larvae community was its high diversity, i.e. the large number of species and their relative low abundance (Margalef, 1974). This characteristic was reflected in the high number of taxa and in the low number of larvae per taxon registered (Table 2). This high diversity appears typical of a subtropical community (Longhurst and Pauly, 1987).

The taxonomic composition (at family level) of the fish larvae community, with four mesopelagic families occupying the first four positions in the rank of frequencies and contributing $85.1 \%$ of the total fish larvae catches, was similar to those found in diverse oceanic regions like the tropical Indian Ocean, the outer oceanic area of the California Current region (Ahlstrom, 1969), the eastern tropical Pacific (Ahlstrom, 1972), the North Pacific Central Gyre (Loeb, 1979a) and the NE Atlantic (Rodríguez, unpublished data) (Table 3). Therefore, the basic taxonomic composition of the ichthyoplankton can be defined as typical of oceanic warm waters regions.

The mesopelagic fish dominate the ichthyofauna in the oceanic regions, both in number of species and in number of individuals (Loeb, 1979b), and this is reflected in the ichthyoplankton community (Loeb, 1979a). In fact, the myctophids, on average, make up approximately one-half of all fish larvae taken in any oceanic plankton tow (Ahlstrom et al., 1976). The data obtained in this study are in agreement with these observations. The most numerous family was Myctophidae. This family and the second most abundant, Gonostomatidae, represented $81.7 \%$ of the fish larvae catches. (The individuals of the family Photichtydae were included in the Family Gonostomatidae for comparability with the works on which the Table 3 is based. Apart from Rodríguez (unpublished data), the first family is not considered as such and the species which constitute it are integrated in the family Gonostomatidae). The adult individuals of these two families contribute between $60 \%$ and $90 \%$ of the total catches of micronektonic fishes in oceanic regions, both in weight and in number, forming the most important groups from the ecological point of 
TABLE 2. - Taxonomic organisation of the fish larvae and numeric percentage of the different taxa.

\begin{tabular}{|c|c|c|c|}
\hline Species & $\%$ & Species & $\%$ \\
\hline Order ISOPONDYLI (CLUPEIFORMES) & & Family NOTOSUDIDAE & \\
\hline SubOrder Clupeoidei & & Ahliesaurus berryi Bertelsen, Kreft \& Marshall, 1976 & 0.07 \\
\hline Family CLUPEIDAE & & Scopelosaurus argenteus (Maul, 1954) & 0.02 \\
\hline Sardina pilchardus (Walbaum, 1792) & 0.01 & Scopelosaurus lepidus (Krefft \& Maul, 1955) & 0.14 \\
\hline Sardinella aurita Valenciennes, 1847 & 0.26 & Family MYCTOPHIDAE & \\
\hline Sardinella maderensis (Lowe, 1838) & 0.17 & Benthosema suborbitale (Gilbert, 1913) & 1.54 \\
\hline Family ENGRAULIDAE & & Ceratoscopelus maderensis (Lowe, 1839) & 0.76 \\
\hline Engraulis encrasicolus (Linnaeus, 1758) & 0.02 & Ceratoscopelus warmingii (Lütken, 1892) & 7.33 \\
\hline SubOrder Stomiatoidei & & Diaphus holti Tåning, 1918 & 4.78 \\
\hline Family GONOSTOMATIDAE & & Diaphus metopoclampus $(\mathrm{Cocco}, 1829)$ & 0.33 \\
\hline Bonapartia pedaliota Goode \& Bean, 1896 & 0.02 & Diaphus rafinesquei (Cocco, 1838$)$ & 1.99 \\
\hline Cyclothone acclinidens Garman, 1899 & 0.74 & Diaphus sp & 0.14 \\
\hline Cyclothone alba? Brauer, 1906 & 0.43 & Diaphus sp 1 & 0.94 \\
\hline Cyclothone braueri Jespersen \& Tåning, 1926 & 11.92 & Diaphus sp 3 & 0.31 \\
\hline Cyclothone pallida Brauer, 1902 & 0.47 & Diaphus sp 6 & 0.02 \\
\hline Cyclothone pseudopallida Mukhacheva, 1964 & 0.28 & Diaphus sp 8 & 0.25 \\
\hline Cyclothone pallida and/or pseudopallida & 0.24 & Diaphus sp 9 & 0.07 \\
\hline Cyclothone sp & 0.02 & Diaphus sp 12 & 0.07 \\
\hline Diplophos maderensis? (Johnson, 1890) & 0.02 & Diaphus sp 13 & 0.17 \\
\hline Diplophos taenia Günther, 1873 & 0.05 & Diaphus spp & 1.87 \\
\hline Gonostoma atlanticum Norman, 1930 & 0.43 & Diogenichthys atlanticus (Tåning, 1928) & 4.74 \\
\hline Gonostoma denudatum Rafinesque, 1810 & 0.47 & Electrona rissoi $(\mathrm{Cocco}, 1829)$ & 0.05 \\
\hline Gonostoma elongatum Günther, 1878 & 2.13 & Hygophum benoiti (Сocco, 1838) & 4.74 \\
\hline Gonostoma sp 1 & 0.01 & Hygophum hygomii (Lütken, 1892) & 0.87 \\
\hline Gonostoma sp 4 & 0.36 & Hygophum macrochir (Günther, 1864) & 0.26 \\
\hline Margrethia obtusirostra Jespersen \& Tåning, 1919 & 0.05 & Hygophum reinhardtii (Lütken, 1892) & 0.55 \\
\hline "Maurolicine alpha" & 0.02 & Hygophum taaningi Bekker, 1965 & 0.20 \\
\hline Unidentified spp & 0.71 & Lampanyctus ater Tåning, 1928 & 0.29 \\
\hline Family STERNOPTYCHIDAE & & Lampanyctus crocodilus (Risso, 1810) & 0.05 \\
\hline Argyropelecus hemigymnus Cocco, 1829 & 0.18 & Lampanyctus pusillus (Johnson, 1890) & 0.83 \\
\hline Argiropelecus sp 1 & 2.82 & Lampanyctus sp 1 & 0.18 \\
\hline Sternoptyx pseudobscura Baird, 1791 & 0.05 & Lampanyctus sp 3 & 0.09 \\
\hline Sternoptyx spp & 0.22 & Lampanyctus sp 4 & 0.15 \\
\hline Valenciennellus tripunctulatus (Esmark, 1871) & 0.11 & Lampanyctus sp 5 & 0.02 \\
\hline Family PHOTICHTHYDAE & & Lampanyctus sp 7 & 0.02 \\
\hline Ichthyococcus ovatus Cocco, 1838 & 0.02 & Lampanyctus spp & 7.98 \\
\hline Vinciguerria attenuata (Соссо, 1838) & 0.07 & Lepidophanes gaussi (Brauer, 1906) & 1.77 \\
\hline Vinciguerria nimbaria (Jordan \& Williams, 1895) & 0.43 & Lobianchia dofleini (Zugmayer, 1911) & 0.07 \\
\hline Vinciguerria poweriae (Cocco, 1838) & 0.38 & Lobianchia gemellarii (Cocco, 1838) & 0.05 \\
\hline Vinciguerria spp & 2.20 & Myctophum nitidulum Garman, 1899 & 0.33 \\
\hline Family ASTRONESTHIDAE & & Myctophum punctatum Rafinesque, 1810 & 0.40 \\
\hline Astronesthidae sp 1 & 0.05 & Myctophum selenops Tåning, 1928 & 0.99 \\
\hline Astronesthidae sp 2 & 0.02 & Notolychnus valdiviae (Brauer, 1904) & 3.15 \\
\hline Unidentified spp & 0.02 & Notoscopelus (Not.) resplendens (Johnson, 1863) & 0.20 \\
\hline Family CHAULIODONTIDAE & & Notoscopelus sp & 0.21 \\
\hline Chauliodus sloani Schneider, 1801 & 0.20 & Symbolophorus rufinus (Tåning, 1928) & 0.68 \\
\hline Family STOMIIDAE & & Symbolophorus veranyi (Moreau, 1888) & 0.05 \\
\hline Stomias boa (Risso, 1810$)$ & 0.05 & Taaningichthys minimus (Tåning, 1928) & 0.02 \\
\hline Stomiidae sp 1 & 0.02 & Myctophidae sp 1 & 0.11 \\
\hline Unidentified spp & 0.08 & Myctophidae sp 2 & 0.09 \\
\hline Family MELANOSTOMIIDAE & & Unidentified spp & 10.58 \\
\hline Eustomias sp & 0.02 & SubOrder Alepisauroidei & \\
\hline Melanostomiidae sp 1 & 0.02 & Family SCOPELARCHIDAE & \\
\hline Melanostomiidae sp 2 & 0.07 & Benthalbella infans Zugmayer, 1911 & 0.29 \\
\hline Unidentified spp & 0.36 & Unidentified spp & 0.02 \\
\hline Family IDIACANTHIDAE & & Family EVERMANNELLIDAE & \\
\hline Idiacanthus fasciola Peters, 1877 & 0.02 & Evermannella balbo (Risso, 1820) & 0.07 \\
\hline SubOrder Salmonoidei & & Family ALEPISAURIDAE & \\
\hline Family ARGENTINIDAE & & Alepisaurus ferox Lowe, 1833 & 0.02 \\
\hline Nansenia oblita (Facciolà, 1887) & 0.02 & Family OMUSUDIDAE & \\
\hline Family BATHYLAGIDAE & & Omosudis lowei Günther, 1887 & 0.02 \\
\hline Bathylagus longirostris Maul, 1948 & 0.07 & Family PARALEPIDIDAE & \\
\hline Unidentified spp & 0.07 & Lestidiops affinis Ege, 1930 & 0.07 \\
\hline Order INIOMI (SCOPELIFORMES) & & Lestidiops jayakari (Boulenger, 1889) & 0.14 \\
\hline SubOrder Myctophoidei & & Lestidiops sphyrenoides (Risso, 1820) & 0.02 \\
\hline Family AULOPIDAE & & Macroparalepis affinis Ege, 1933 & 0.05 \\
\hline Aulopus filamentosus? (Bloch 1792) & 0.01 & Paralepis atlantica Krøyer, 1868 & 0.26 \\
\hline Family SYNODONTIDAE & & Sudis hyalina Rafinesque, 1810 & 0.05 \\
\hline Synodus saurus (Linnaeus, 1758) & 0.20 & Unidentified spp & 0.07 \\
\hline Synodus synodus (Linnaeus, 1758) & 0.07 & Order APODES (ANGUILLIFORMES) & \\
\hline Family CHLOROPHTHALMIDAE & & Family NETTASTOMATIDAE & \\
\hline Chlorophthamus agassizii Bonaparte, 1840 & 0.20 & Unidentified spp & 0.22 \\
\hline
\end{tabular}


TABLE 2. (Cont.) - Taxonomic organisation of the fish larvae and numeric percentage of the different taxa.

\begin{tabular}{|c|c|c|c|}
\hline Species & $\%$ & Species & $\%$ \\
\hline Family SERRIVOMERIDAE & & Unidentified spp & 0.03 \\
\hline Serrivomer beani Gill \& Rider, 1884 & 0.09 & SubOrder Gobiodei & \\
\hline Family: CONGRIDAE & & Family GOBIIDAE & \\
\hline Ariosoma balearicum (Delaroche, 1809) & 0.02 & Unidentified spp & 2.32 \\
\hline Unidentified spp & 0.07 & SubOrder Callionymoidei & \\
\hline Family OPHICHTHIDAE & & Family CALLIONYMIDAE & \\
\hline Ophichthidae sp 2 & 0.02 & Callionymus sp & 0.01 \\
\hline Unidentified spp & 0.02 & SubOrder Ophidioidei & \\
\hline Order SYNETOGNATHI (BEOLONIFORMES) & & Family: OPHIDIIDAE & \\
\hline SubOrder Scomberesocoidei & & Parophidion vassali (Rissso, 1810) & 0.07 \\
\hline Family BELONIDAE & & Ophidiidae sp 1 & 0.02 \\
\hline Platybelone argalus (Le Sueur, 1821) & 0.03 & Ophidiidae sp 2 & 0.05 \\
\hline Family SCOMBEROSOCIDAE & & Unidentified spp & 0.05 \\
\hline Scomberosox saurus (Walbaum, 1792) & 0.03 & Family CARAPIDAE & \\
\hline Order SOLENICHTHYES (SYNGNATHIFORMES) & & Carapus acus (Brünnich, 1768) & 0.02 \\
\hline SubOrder Centriscoidei & & SubOrder Stromateoidei & \\
\hline Family MACRORAMPHOSIDAE & & Family: CENTROLOPHIDAE & \\
\hline Macroramphosus scolopax (Linnaeus, 1758) & 0.85 & ?Schedophilus ovalis (Valenciennes, in Cuv. Val., 1833) & 0.05 \\
\hline Order ANACANTHINI (GADIFORMES) & & Family: NOMEIDAE & \\
\hline Family MACROURIDAE & & Nomeidae sp 1 & 0.11 \\
\hline Unidentified spp & 0.07 & Unidentified spp & 0.02 \\
\hline Order BERYCOMORPHI (BERYCIFORMES) & & Family TETRAGONURIDAE & \\
\hline Family MELAMPHAIDAE & & Tetragonurus atlanticus Lowe, 1939 & 0.09 \\
\hline Melamphaes simus Ebeling, 1962 & 0.05 & Tetragonurus cuvieri Risso, 1810 & 0.18 \\
\hline Melamphaes thyplops? (Lowe, 1843) & 0.05 & SubOrder Mugiloidei & \\
\hline Melamphaes sp 1 & 0.02 & Family MUGILIDAE & \\
\hline Order ZEOMORPHI (ZEIFORMES) & & Unidentified spp & 0.29 \\
\hline Family CAPROIDAE & & Order SCLEROPAREI (SCORPAENIFORMES) & \\
\hline Antigonia capros Lowe, 1843 & 0.01 & SubOrder Scorpaenoidei & \\
\hline Order PERCOMORPHI (PERICIFORMES) & & Family SCORPAENIDAE & \\
\hline SubOrder Percoidei & & Scorpaena scrofa? Linnaeus, 1758 & 0.02 \\
\hline Family SERRANIDAE & & Scorpaenidae sp 1 & 0.02 \\
\hline Anthias anthias (Linnaeus, 1758) & 0.05 & Scorpaenidae sp 2 & 0.02 \\
\hline Epinephelus sp & 0.02 & Scorpaenidae sp 3 & 0.07 \\
\hline Family CARANGIDAE & & Scorpaenidae sp 5 & 0.02 \\
\hline Carangidae sp 1 & 0.02 & Order HETEROSTOMA (PLEURONECTIFORMES) & \\
\hline Unidentified spp & 0.05 & SubOrder Pleuronectoidei & \\
\hline Famila SPARIDAE & & Family BOTHIDAE & \\
\hline Pagellus acarne? (Risso, 1826) & 1.05 & Arnoglossus thori Kyle, 1913 & 0.17 \\
\hline Pagellus bogaraveo? (Brünnich, 1768) & 0.02 & Bothus podas maderensis (Lowe, 1834) & 0.38 \\
\hline Pagellus sp & 0.02 & Family SOLEIDAE & \\
\hline Unidentified spp & 0.29 & Unidentified spp & 0.02 \\
\hline Family LABRIDAE & & Family CYNOGLOSSIDAE & \\
\hline SubFamily Corinae & & Symphurus nigrescens Raffinesque, 1810 & 0.05 \\
\hline Coris julis (Linnaeus, 1758) & 0.07 & Order PLECTOGNATIHI (TETRAODONTIFORMES) & \\
\hline Thalassoma pavo (Linnaeus, 1758) & 0.14 & SubOrder Balistoidei & \\
\hline Xyrichthys novacula (Linnaeus, 1758 ) & 0.09 & Family MONACANTHIDAE & \\
\hline Unidentified spp & 0.02 & Stephanolepis hispidus (Linnaeus, 1766) & 0.02 \\
\hline Family SCARIDAE & & Family TETRAODONTIDAE & \\
\hline Sparisoma (Euscarus) cretense (Linnaeus, 1758) & 0.29 & Sphoeroides spp & 0.05 \\
\hline Family TRACHINIDAE & & Tetraodontidae sp 1 & 0.02 \\
\hline Trachinus draco Linnaeus, 1758 & 0.07 & Tetraodontidae sp 2 & 0.02 \\
\hline SubOrder Trichiuroidei & & Order PEDICULATI (LOPHIIFORMES) & \\
\hline Family GEMPYLIDAE & & SubOrder Ceratioidei & \\
\hline Diplospinus multistriatus Maul, 1948 & 0.60 & Family MELANOCETIDAE & \\
\hline Nesiarchus nasutus Johnson, 1862 & 0.31 & Melanocetus murrayi Günther, 1887 & 0.05 \\
\hline Family TRICHIURIDAE & & Melanocetus spp & 0.05 \\
\hline Benthosdemus elongatus simonyi (Steindachner, 1891) & 0.09 & Family ONEIRODIDAE & \\
\hline Lepidopus caudatus (Eupharsen, 1788) & 0.07 & Chaenoprhyne draco Beebe, 1932 & 0.02 \\
\hline Trichiuridae sp 1 & 0.02 & Dolopichthys sp & 0.02 \\
\hline Unidentified spp & 0.02 & Family GIGANTACTINIDAE & \\
\hline SubOrder Scombroidei & & Gigantactis sp 1 & 0.02 \\
\hline Family SCOMBRIDAE & & & \\
\hline
\end{tabular}

view (Gjøsaeter and Kawaguchi, 1980). Moreover, according to these authors, it is in the tropical and subtropical regions where the number of species and, in general, their annual production is highest. Like- wise, according to Horn (1980), the mesopelagic fishes, especially the myctophids, seem to occupy a position in the trophic structure of oceanic waters similar to that of the northern anchovy (Engraulis 
TABLE 3. - Percentage of the fish larvae catches for the three most frequent mesopelagic fish families in different marine regions.

\begin{tabular}{lccccrr}
\hline & Canary region & $\begin{array}{c}\text { Indian } \\
\text { Ocean }\end{array}$ & $\begin{array}{c}\text { East tropical } \\
\text { Pacific }\end{array}$ & $\begin{array}{c}\text { California } \\
\text { Current }\end{array}$ & $\begin{array}{c}\text { North Central } \\
\text { Pacific }\end{array}$ & NE Atlantic \\
\hline F. Myctophidae & $\mathbf{6 0 . 2 6}$ & 47.6 & 52.0 & 46.7 & 45.90 & 44.71 \\
F. Gonostomatidae + F. Photichtydae & $\mathbf{2 1 . 4 7}$ & 30.5 & 19.7 & 34.8 & 32.40 & 35.20 \\
F. Sternoptychidae & $\mathbf{3 . 3 8}$ & 78.1 & 77.0 & 81.5 & 8.05 & 5.29 \\
Total & $\mathbf{8 5 . 1 1}$ & 73.35 & 85.20 \\
\hline
\end{tabular}

mordax) in more shallow and coastal waters of the California Current region.

The family Myctophidae was the one that presented the highest specific diversity. This family contributes the greatest number of species to the mesopelagic fish community. Of the approximately 700 species of fish that inhabit the mesopelagic region (Parin, 1984), around 235 are myctophids (Nelson, 1994). At the larval level, this family has frequently been referred to as the one that presents the greatest number of species in different marine regions, eg. in NW Africa (Palomera and Rubies, 1982; Sabatés and Rubies, 1985), the western Mediterranean (Massó and Palomera, 1984) and in the North Pacific Central Gyre (Loeb, 1979a and b).

Moreover, the most frequently caught species, Cyclothone braueri, has often also been the most numerous in oceanic hauls, both larvae and adults. In studies carried out in a zone near our study area, to the north of the island of Fuerteventura, the adults of this species were the most abundant (Badcock, 1970, Badcock and Merrett, 1976). In the NE Atlantic the larvae of this species (Rodríguez, unpublished data) and in the Sargasso Sea, their adults (Backus et al., 1969), were the most captured species. The same is true of the larvae in the western Mediterranean (Massó and Palomera, 1984) and both of larvae and adults of this species in the whole of the Mediterranean (Goodyear et al., 1972; Jespersen and Tåning, 1926). In the North Pacific Central Gyre the larvae of C. alba (Loeb, 1979b, 1980), and also in the South Pacific Central Gyre, the adults of $C$. alba (Barnett, 1983, 1984) replaced $C$. braueri as the most captured species.

A possible explanation for the presence in the ichthyoplankton community of a typical oceanic ichthyoplankton species together with relatively abundant larvae of very coastal species (family Gobiidae) could be the virtual absence of an island shelf around Gran Canaria. Because of this, typically oceanic conditions would occur very near the coast and their influence would be felt there. In fact, the two stations with the greatest concentration of gobid larvae and a smaller percentage of oceanic larvae were two coastal stations sampled during the second leg of this cruise with one located to the north and the other to the south of this island. These two stations, because of particular conditions of water circulation around Gran Canaria (Van Camp et al., 1991; Hernández-Guerra et al., 1993; Arístegui et al., 1994, 1997; Barton et al., 1998; Martínez et al., 1999; Rodríguez et al., unpublished data) would have been those that presented more neritic characteristics.

\section{ACKNOWLEDGEMENTS}

This study was carried out within the framework of the project "MAST project 0031" financed by the European Commission and the Instituto Español de Oceanografía. The author wishes to thank Dr. E. D. Barton for help with the English. The comments on the manuscript made by the anonymous Referee 1 were greatly appreciated.

\section{REFERENCES}

Ahlstrom, E.H. - 1969. Mesopelagic and bathypelagic fishes in the California Current Region. Calif. Mar. Res. Comm., CalCOFI Rept., 13: 39-44.

Ahlstrom, E.H. - 1972. Kinds and abundance of fish larvae in the eastern tropical Pacific on the second multivessel EASTROPAC survey, and observations on the annual cycle of larval abundance. Fish. Bull. U. S., 74(4): 1143-1242.

Ahlstrom. E.H., H.G. Moser and M.J. O'Toole. - 1976. Development and distribution of larvae and early juveniles of the commercial lanternfish, Lampanyctodes hectoris (Günther), off the west coast of Southern Africa with discussion of phylogenetic relationships of the genus. Bull. S. Calif. Acad. Sci. 75(2): 138152.

Andres, H.G. and H-Ch. John. - 1984. Results of some neuston net catches in the warmer Central North Atlantic - Fish larvae and selected invertebrates. Meeresforsch., 30: 144-154.

Arístegui, J., P. Sangrá, S. Hernández-León, M. Cantón, A. Hernández-Guerra, J.L. Kerling. 1994. - Island-induced eddies in the Canary Islands. Deep-Sea Res. I, 41(10): 1509-1525.

Arístegui, J., P. Tett, A. Hernández-Guerra, G. Basterretxea, M.F. Montero, K. Wild, P. Sangrá, S. Hernández-León, M. Cantón, J.A. García-Braun, M. Pacheco and E.D. Barton. - 1997. The influence of island-generated eddies on chlorophyll distribution: a study of mesoscale variation around Gran Canaria. Deep-Sea Res. I, 44(1): 71-96. 
Backus, R.H., J.E. Craddock, R.L. Haedrich and D.L. Shores. 1969. Mesopelagic fishes and thermal fronts in the western Sargasso Sea. Mar. Biol., 3: 87-106.

Badcock, J. - 1970. The vertical distribution of mesopelagic fishes collected on the Sond Cruise. J. mar. biol. Ass. U.K., 50: 10011044.

Badcock, J. and N.R. Merrett. - 1976. Midwater fishes in the eastern North Atlantic-I. Vertical distribution and associated biology in $30^{\circ} \mathrm{N}, 23^{\circ} \mathrm{W}$, with developmental notes on certain myctophids. Prog. Oceanogr., 7: 3-58.

Barnett, M.A. - 1983. Species structure and temporal stability of mesopelagic fish assemblages in the Central Gyres of the North and South Pacific Ocean. Mar. Biol., 74: 245-256.

Barnett, M. A. - 1984. Mesopelagic fish zoogeography in the central tropical and subtropical Pacific Ocean: species composition and structure at representative locations in three ecosystems. Mar. Biol., 82: 199-208.

Barton, E.D., J. Arístegui, P. Tett, J. García-Braun, S. HernándezLeón, L. Nikjær, C. Almeida, S. Ballesteros, G. Basterretxea, J. Escánez, L. García-Weill, A. Hernández-Guerra, F. LópezLaatzen, R. Molina, M.F. Montero, E. Navarro-Pérez, J.M. Rodríguez, H. Vélez and K. Wild. - 1998. The transition zone of the Canary Current upwelling region. Prog. Oceanogr., 41: 455-504.

Gjøsaeter, J. and K. Kawaguchi. - 1980. A review of the world resources of mesopelagic fishes. FAO Fisheries Technical Paper, 193, $151 \mathrm{pp}$.

Goodyear, R.H., B.J. Zauranec, W. Lawrence and R.H. Gibs, Jr. 1972. Ecology and vertical distribution of mediterranean midwater fishes. Mediterr. Biol. Stud. Limnol. Rep., 1: 91-229.

Hempel, G. and H. Weikert. - 1972. The neuston of the subtropical and boreal north-eastern Atlantic Ocean. A review. Mar. Biol., 13: 70-88.

Hernández-Guerra, A., J. Arístegui and M. Cantón. - 1993. Phytoplankton pigment patterns in the Canary Islands area as determined using Coastal Zone Colour Scanner data. Int. J. Remote Sen., 14(7): 1431-1437.

Horn, H.M. - 1980. Diversity and ecological roles of noncommercial fishes in California marine habitats. CalCOFI Rep., XXI: 37-47.

Hureau, J.C. and Th. Monod (eds.). - 1979. Check-list of the fishes of the north-eastern Atlantic and Mediterranean with supple ment 1978. (CLOFNAM). Unesco, París. Vol. I-II. (Supplement: Tortonese, E. and J. C. Hureau. 1979. Clofnam, Supplément 1978, Les Presses de 1’Unesco. Cybium, $3^{\mathrm{e}}$. série (5) 5[333]-66[394].

Jespersen, P. and A.V. Tåning. - 1926. Mediterranean Sternoptychidae. Rep. Dan. Oceanogr. Exped. Mediterr. 2.(A.12): 59 pp.

John, H-Ch. - 1976. Die häufigkeit des ichthyoplanktons an der Oberfläche des mittleren und slichen Atlantishen Ozeans. Meeresforsch., 25: 23-36.
John, H-Ch. - 1979. Regional and seasonal differences in ichthyoneuston off Northwest Africa. Meteor Forsch.-Ergebnisse, 29: $30-47$.

Loeb, V.J. - 1979a. Larval fishes in the zooplankton community of the North Pacific Central Gyre. Mar. Biol., 53: 173-191.

Loeb, V.J. - 1979b. Vertical distribution and development of larval fishes in the North Pacific Central Gyre during summer. Fish. Bull., 77(4): 777-793.

Loeb, V.J. - 1980. Patterns of spatial and species abundance within the larval fish assemblage of the North Pacific Central Gyre during late summer. Mar. Biol., 60: 189-200.

Longhurst, A.R. and D. Pauly. - 1987. Ecology of tropical oceans. Academic Press, San Diego.

Margalef, R. - 1974. Ecología. Ediciones Omega, Barcelona.

Martínez, A, E. Pérez and M. Bruno. - 1999. Variation of the tidal properties around Gran canaria. Oceanologica Acta, 22(1): 1930.

Massó, M., and I. Palomera. - 1984. Distribución vertical de fases larvarias de peces meso y batipelágicos del Mediterráneo occidental. Inv. Pesq., 48(3): 455-468.

Nelson, J.S. - 1994. Fishes of the world. Third edition. John Willey \& Sons, New York.

Palomera, I. and P. Rubies. - 1982. Kinds and distribution of fish eggs and larvae off Northwest Africa April-May 1973. Rapp. P.-v. Réun. Cons. int. Explor. Mer, 180: 356-358.

Parin, N.V. - 1984. Oceanic ichthyologeography: an attempt to review the distribution and origin of pelagic and bottom fishes outside continental shelves and neritic zones. Arch. FishWis., 35(1): 5-41.

Rodríguez, J.M. and F. Lozano-Soldevilla. - 1993. Cruise "CANARIAS 9206". Preliminary results on composition, abundance and horizontal distribution of ichthyoplankton. ICES C.M./L: $24: 7 \mathrm{pp}$.

Rodríguez, J.M. F. Lozano-Soldevilla and G. Lozano - 1996. Ictioplancton del Sur de Tenerife (Campaña IEO Canarias 9310). Bol. R. Soc. Esp. Hist. Nat. (Tomo Extraordinario 125 Aniversario): $225-228$.

Sabatés, A. and P. Rubíes. - 1985. Distribución y abundancia de larvas de mictófidos y gonostomátidos en el Noroeste de Africa. In: C. Bas, R. Margalef and R. Rubíes (eds.), Int. Simp. Upw. W Afr., Inst. Inv. Pesq., Barcelona, 1: 513-522.

Van Camp, L., L. Nykjær, E. Mittelstaedt, and P. Schlittenhardt. 1991. Upwelling and boundary circulation off Northwest Africa as depicted by infrared and visible satellite observations. Prog. Oceanogr., 26: 357-402.

Whithehead, P.J.P., M. L. Bauchot, J.C. Hureau, J. Nielsen and E. Tortonesse (eds.). - 1984. Fishes of the North-eastern Atlantic and the Mediterranean. UNESCO, U. K. Vo1. I-III.

Scient. ed.: P. Jonsson 